\title{
Financial Reforms and Technical Efficiency in Indian Commercial Banking: A Generalized Stochastic Frontier Analysis
}

\author{
Aditi Bhattacharyya* $\quad$ Sudeshna Pal ${ }^{\dagger}$
}

\begin{abstract}
November 2011
Abstract

In this study we estimate technical efficiency of Indian commercial banks from 19892009 using a multiple-output generalized stochastic production frontier, and analyze the effects of financial sector reforms on measured efficiency. This generalized technique estimates technical efficiency in the presence of multiple outputs, filling a gap in the existing literature. Our results show that Indian commercial banks were operating with $64 \%$ efficiency on average during the sample period and that efficiency declined in both public and private banks during most parts of the post-reform period. The capital adequacy ratios negatively influenced efficiency while the number of branches had no significant effect on bank efficiency. Financial sector reforms, however, have had mixed results on technical efficiency. The initial phase of reform had positive impact on technical efficiency while the later phases adversely affected technical efficiency of commercial banks. Throughout the sample period, public sector banks show higher efficiency levels compared to private sector and foreign banks.
\end{abstract}

JEL Code: D24; G21; G28

Keywords: Technical Efficiency; Generalized Stochastic Production Frontier; Indian Commercial Banks; Financial Reforms; Liberalization

*Department of Economics and International Business, Sam Houston State University, Huntsville, TX 77341.

Ph: 936-294-4791. Email: aditibhattacharyya@gmail.com

${ }^{\dagger}$ Department of Economics and Finance, Georgia College and State University, CBX No. 014, Milledgeville, GA 31061. Ph: 478-445-1240. Email: sudeshna.pal@gcsu.edu 


\section{Introduction}

The goal of this study is to estimate technical efficiency of Indian commercial banks and examine the effects of financial sector reforms on the measured efficiency. The role of the financial sector in promoting economic growth and development has been widely acknowledged in the literature (e.g. Schumpeter (1911); Goldsmith (1969); Mckinnon (1973); Shaw (1973); Fry (1978); King and Levine(1993a, 1993b); Levine (2005)). Studies show that "financial repression" or the existence of rigid government control on interest rate and lending policies of banks and other financial institutions, under-lending, high uncertainty on returns on savings and investments and misallocation of savings among competing users, among other things, stunts the development of the financial sector and further hinders economic growth in both developed and developing countries(e.g. Fry(1980, 1997); Haber (2003); Barth et al. (2006); Abiad et al. (2008).

The financial sector in post-independence India had all the characteristics of financial repression. Banks were nationalized and there was strong government control over the financial market. "The sector was characterized, inter alia, by administered interest rates, large preemption of resources by the authorities and extensive micro-regulations directing the major portion of the flow of funds to and from financial intermediaries" (Mohan 2004, p 851). The outcome was lack of competition, high intermediation costs and hence under-lending, corruption and bureaucratic lethargy (e.g. Banerjee et al. (2004); Mohan (2005); Thomas (2005)). In 1991 the Indian government launched wide-spread economic liberalization policies which also pervaded the financial sector. Entry barriers were loosened making way for private and foreign banks, reforms were initiated to improve "financial soundness" and bank efficiency targeting capital adequacy requirements, stronger vigilance of the banking sector and several other legal and institutional factors (Ahluwalia (2002); Mohan (2005)). The banking sector reforms in India were implemented in two phases, first in 1991-92 followed by a second phase in 1998.

India presents an interesting case in the study of bank efficiency owing to the co-existence of a large number of government owned, private and foreign banks in the economy. India's rapid economic growth also makes examination of the performance of the banking sector an attractive subject for research, especially, after the implementation of widespread economic reforms. 
A bank is said to be technically inefficient if the actual output is lower than the maximum possible output level, given available resources. Common causes of such inefficiency includes managerial error or co-ordination failure. The existing literature in this field uses mainly two types of methods to measure technical efficiency of banks - Data Envelopment Analysis (DEA) and Stochastic Frontier Analysis (SFA).

The DEA method uses linear programming techniques to measure efficiency of production units that produce multiple outputs. Several studies use this approach to measure efficiency of Indian banks (see Bhattacharyya, Lovell, and Sahay (1997); Sathye (2003); Das and Ghosh (2006); Das, Nag, and Ray (2005); Kumar and Gulati (2009)). However, this method fails to capture the effect of random shocks to the production system. On the other hand, the SFA method posits two main causes for the deviation of actual output from the maximum possible output, given the inputs. A part of this deviation is attributed to the symmetric random shocks to a production system that are not under the control of a producer (e.g., uncertainty about the environment, or input market conditions). The other part is attributed to factors such as managerial error and coordination failures. The existing studies that use SFA to measure different types of efficiency of Indian banks either focus on measuring cost and profit efficiency in monetary terms to avoid the problem of considering multiple output (see Sensarma (2006), Zhao et al. (2010)), or measure technical efficiency using a simple production model with one type of output only (see Shanmugam and Das (2004)). In reality, banks produce many financial services (outputs) using a given set of inputs, and none of the existing studies use the stochastic frontier approach to measure technical efficiency of banks in such a framework.

In this paper, we use the Generalized Stochastic Frontier Production Model that allows for the possibility of multiple outputs in a production system, as introduced by Löthgren(1997), and measure time-varying technical efficiency of Indian banks. Further, we analyze effects of financial reforms and other bank specific characteristics on the measured efficiency scores using a panel data spanning the period from 1989 to 2009.

Our study finds that the average technical efficiency of both public and private sector commercial banks in India is low and declined during most parts of the period under consideration, showing an improvement only towards the end of the sample period. Capital adequacy ratio negatively influenced technical efficiency of Indian commercial banks, particularly, the private 
banks. Although the gradual process of financial reforms, as experienced by the country for last two decades, shows some positive impact on technical efficiency of banks in the beginning, the effect seems to die down thereafter.

Our finding of a declining trend in efficiency levels of Indian banks over time, is in accordance with a study by Das and Ghosh (2006), which uses DEA to measure technical efficiency of Indian banks over the period 1992-2002. Another study by Zhao, Casu, and Ferrari (2010) also finds declining cost-efficiency in Indian banking over the period from 1992 to 2004. Our study encompasses a longer period of time than Das and Ghosh (2006) and Zhao et.al. (2010), and uses a more general technique of efficiency measurements as compared to DEA and the traditional single-output SFA.

The following section briefly outlines the general structure of the Indian commercial banks and the reform programs that were initiated from the early 1990s. Section 3 presents details about the data used in this study and the empirical model specifications. The empirical findings are discussed in section 4 , and section 5 concludes.

\section{A Brief Overview of the Indian Banking Sector}

India's banking sector is characterized by public sector banks, private sector banks and foreign banks. In the 1950s the financial sector in India had limited government control on interest rates and low statutory pre-emption of funds resulting in unequal distribution and misallocation of credit. This was not only defying the free market mechanism of credit allocation but also depriving sectors that were in true need of credit (Das and Kumbhakar (2010)). In order to ensure more equitable distribution of credit, the government tightened its control over banks' credit allocation procedures and nationalized 20 major commercial banks between 1969-1980 (Das et al. (2005)). Consequently, administered interest rates, large pre-emption of resources by the authorities and extensive micro-regulations directing the major portion of the flow of funds to and from financial intermediaries, inter alia, characterized the Indian financial sector in the 1980s. Government controls and regulations also created strong entry barriers. In the absence of competition, India's financial sector was rendered inefficient and non-competitive creating severe credit constraints for other sectors of the economy (Mohan (2005), Thomas (2005)). 
Banking sector reforms in India that were initiated in the early 1990s was a gradual and steady process. One can identify two distinct phases of these reforms. The first phase began with the formation of the Committee on the Financial System (The Narasimhan Committee) in 1991 and the second phase of reforms initiated with the formation of the Banking Sector Reforms Committee (Narasimhan Committee II) in 1998. Both committees recommended widespread reforms for the banking system, capital markets and the insurance sector. Banking sector reforms included various liberalization policies, such as relaxing controls on interest rates and the sanction of large loans by the Reserve Bank of India, and policies that promote competition, such as designing liberal norms for entry of private and foreign banks and insurance companies, and allowing inflow of foreign direct investment in the financial sector. The reforms also included measures to improve "financial soundness", like capital adequacy requirements, stronger vigilance of the banking sector and several institutional and legal measures to improve bank efficiency (Ahluwalia (2002); Mohan (2005)).

These reforms resulted in the expansion of private and foreign banks in India while lowering the share of public sector banks' assets in total bank assets. The share of public sector banks' assets in total assets declined from $92 \%$ in $1990-91$ to $75 \%$ in $2003-04$; at the same time the share of private sector banks went up from $4 \%$ in $1990-91$ to $19 \%$ in $2003-04$. The fact that the banking sector became more competitive following the reforms is shown by the reduction in the ten-firm concentration ratio of 92.86 in 1991-92 to 62.99 in 2004-05 (Thomas (2005)).

\section{Data and Econometric Model Specification}

\subsection{Data}

Technical efficiency is measured using bank level data from the Prowess database obtained from Center for Monitoring the Indian Economy (CMIE). Prowess has audited financial data on financial sector companies of which we consider companies providing commercial banking services only. The data also provides information on bank ownership, namely, public and private and further categories such as Indian private banks and foreign private banks. Our data consists of an unbalanced panel of upto 103 commercial banks from 1989-2009. 
The common practice is to adopt either an intermediary approach or a production approach to measure technical efficiency of banks. The two approaches use different sets of outputs and inputs. Based on data availability we follow the intermediary approach, under which banks produce intermediation services like investments, loans and advances through the collection of liabilities like deposits. This approach also includes expenses for hiring labor and renting capital as inputs of the banking system. Hence we estimate technical efficiency using bank level data on three input variables - compensation to employees and capital expenses (calculated by aggregating expenditures on power and fuel, indirect taxes, rent and lease, repairs, insurance premium, printing, stationary and depreciation) and deposits accepted by commercial banks. The output of banks is defined as a mix of investments, and loans and advances. We describe the basic method to construct the output mix from these two outputs in section 3.2. ${ }^{1}$

We measure financial reforms by constructing dummies for several time periods to take into account the gradual nature of the liberalization process. The time dummies are 1993-1996, 1998-2001, 2002-2005 and 2006-2007. The empirical model that estimates the effects of reforms on technical efficiency of banks also controls for bank specific factors such as number of branches and capital adequacy ratio. Number of branches controls for managerial inefficiencies that might set in when a bank has too many branches and negatively affect technical efficiency (Das and Ghosh (2006)). Capital adequacy ratio (CAR) accounts for the degree of capitalization of banks. Banks with a high capital adequacy ratio can be considered safe, decreasing their cost of borrowing and hence increasing efficiency (Das and Ghosh (2006)). On the other hand a high CAR may imply conservative behavior on the part of banks in terms of lending, leading to lower efficiency (Bhattacharyya et al. (1997)).

Both regression models use logarithmic values of dependent and independent variables (except time trend and time dummies). Table 1 presents the summary statistics of the data used in our analysis. Appendix A provides a detailed description of the variables.

\footnotetext{
${ }^{1}$ Appendix B presents the detailed method of constructing the output mix.
} 


\subsection{Model Specification}

We specify a panel data stochastic production frontier model for Indian commercial banks in a generalized production frontier framework (Löthgren(1997)), also known as the Ray Production Frontier, as discussed in Appendix B. The Ray Production Frontier considers multiple outputs produced by banks, and constructs an output measure based on the production possibility frontier representing the relationship among the outputs. The polar co-ordinate angles between the output vectors play an important role in determining the relationship between the output measure and inputs. Let $i=1, \ldots, N$ be the number of banks, $t=1, \ldots, T$ be the number of time periods under consideration, and $p=1, \ldots, P$ be the number of outputs generated by every bank. Assuming that the banking services are generated by a Cobb-Douglas function ${ }^{2}$, the generalized stochastic production model $^{3}$ is given by

$$
\ln \left\|y_{i t}\right\|=\beta_{0}+z_{i t}^{\prime} \beta+v_{i t}-u_{i t}, i=1, \ldots N ; t=1, \ldots, T
$$

$$
\begin{aligned}
\text { where }\left\|y_{i t}\right\| & =\left(\sum_{p=1}^{P}\left(y_{i t}^{p}\right)^{2}\right)^{1 / 2}, p=1, \ldots, P \\
y_{i t}^{p} & =\text { the } p \text { th output (in logarithmic terms) produced by bank } i \text { at time } t \\
\beta_{0} & =\text { the frontier intercept } \\
\beta & =\text { the vector of technology parameters } \\
z_{i t} & =\text { the vector including } d \text { inputs, } P-1 \text { polar-coordinates, time trend, } \\
\text { and other possible exogenous variables that vary with bank and time } & \\
v_{i t} & =\text { random shocks that affect service provision by the banks; } v_{i t} \sim N\left(0, \sigma_{v}^{2}\right) \\
u_{i t} & =\text { technical inefficiency of bank } i \text { at time } t ; u_{i t} \geq 0
\end{aligned}
$$

All the variables used in equation (3.2.1) are in their natural logarithmic forms except for the time trend.

\footnotetext{
${ }^{2} \mathrm{~A}$ flexible form production function can be used as well. However, the technical efficiency scores, as calculated using Cobb-Douglas and Trans-logarithmic production functions, are similar for our data.

${ }^{3}$ A detailed discussion on the generalized stochastic production frontier is presented in Appendix B.
} 
We use the Battesse-Coelli (1992) parameterization of the time-varying inefficiency term which is modeled as a truncated normal variable multiplied by a specific function of time. Formally,

$$
u_{i t}=\{\exp [-\eta(t-T)]\} u_{i}, t \in I(i) ; i=1, \ldots, N
$$

where, $u_{i}=i i d$ non-negative truncations of $N\left(\mu, \sigma_{u}^{2}\right)$

$\eta=$ unknown scalar parameter capturing the variation in technical inefficiency with time $I(i)=$ set of $T_{i}$ time periods among the $\mathrm{T}$ periods involved for which observations for the ith banks are obtained.

For $\eta>0$ (or $\eta<0$ ), banks tend to improve (or reduce) their level of technical efficiency over time, and the technical efficiency level tends to remain constant over time for $\eta=0$. The maximum likelihood estimation of (3.2.1) and (3.2.2) is discussed in Battesse and Coelli (1992).

In order to estimate the effects of financial reforms on efficiency in Indian banks, we further model the technical efficiency scores, using a fixed effects panel data regression model ${ }^{4}$ which is given by

$$
\ln u_{i t}=\delta_{0}+\sum_{j=1}^{m} \delta_{j} q_{j i t}+\varepsilon_{i t}
$$

where, $q_{i t}$ is a vector of reform dummies and other bank and time specific explanatory variables (in logarithmic terms) associated with technical efficiency.

To estimate technical efficiency scores of each bank at every time period, we first estimate the generalized stochastic production frontier, as described in equation (3.2.1) where the output norm $\left\|y_{i t}\right\|$ is derived using two outputs, viz. investment and loans and advances (ladv), following Das and Ghosh (2006). Using the values for these two outputs, we measure the output norm as

$$
\left\|y_{i t}\right\|=\left(\text { investment }{ }_{i t}^{2}+l a d v_{i t}^{2}\right)^{1 / 2}
$$

\footnotetext{
${ }^{4}$ We model technical efficiency as a fixed effects model, allowing for the possible correlation between the random shocks affecting technical efficiency of banks and bank specific factors that influence efficiency. However, the estimation results for (3.2.3) using a random effects model and a fixed effects model are very similar.
} 
Inputs used by banks in the production of services like investment and loans and advances are the deposits accepted by them, capital, and employees. Hence, we include the value of deposits accepted by commercial banks (deposits), compensation to employees (labor) and capital expenses (capital) as inputs in the production model. We use the polar-coordinate angle $\theta_{\text {inv }}($ radian) corresponding to the output vector "investment" as another determinant of the output norm. Finally, we capture the effect of technological changes on the production frontier by incorporating the time trend (yearid) in the production model and estimate the frontier model as

$$
\begin{aligned}
\ln \left\|y_{i t}\right\| & =\beta_{0}+\beta_{1} \ln (\text { deposits })+\beta_{2} \ln (\text { labor })+\beta_{3} \ln (\text { capital })+\beta_{4} \ln \left(\theta_{i n v}(\text { rad })\right) \\
& +\beta_{5}(\text { yearid })+v_{i t}-u_{i t}
\end{aligned}
$$

The time-varying technical efficiency scores are then estimated using (3.2.2).

In the next stage, we analyze the effects of financial reforms on technical efficiency scores. Since the reforms were implemented in phases, we construct several dummies for different time intervals. The dummies are described below ${ }^{5}$. We also control for certain bank specific factors, namely, number of branches and capital adequacy ratio which may also have influenced technical efficiency of banks.

$$
\begin{aligned}
\ln u_{i t} & =\delta_{0}+\delta_{1} \ln (\text { branches })+\delta_{2} \ln (\text { CAR })+\delta_{3}(1993-1996) \\
& +\delta_{4}(1998-2001)+\delta_{5}(2002-2005)+\delta_{6}(2006-2009) \\
\text { where }, & \\
\ln \left(u_{i t}\right) & =\ln (\text { technical efficiency }) \\
\ln (\text { branches }) & =\ln (\text { no. of branches }) \\
\ln (\text { CAR }) & =\ln (\text { capital adequacy ratio }) \\
1993-1996 & =1 \text { if } 1992<\text { year }<1997,0 \text { otherwise } \\
1998-2001 & =1 \text { if } 1997<\text { year }<2002,0 \text { otherwise } \\
2002-2005 & =1 \text { if } 2001<\text { year }<2006,0 \text { otherwise } \\
2006-2009 & =1 \text { if } 2005<\text { year }, 0 \text { otherwise }
\end{aligned}
$$$$
+\delta_{4}(1998-2001)+\delta_{5}(2002-2005)+\delta_{6}(2006-2009)+\varepsilon_{i t}
$$

\footnotetext{
${ }^{5}$ Since major phases of reforms were introduced in 1992 and 1997, we measure the effects of reforms post 1992 and 1997 and construct our dummies accordingly.
} 
We also estimate the above model according to ownership groups and analyze impacts of exogenous variables on the technical efficiency scores, separately for each category. For this purpose, we divide the data as banks owned by the government sector or public sector banks and private sector (foreign and domestic) banks.

\section{Empirical Results}

\subsection{Results of Efficiency Analysis}

Estimation results for the generalized production frontier model (equations 3.2.5 and 3.2.2) are presented in Table 2. All three inputs have positive input elasticities. This in turn, also verifies the positive input monotonicity of the ray production frontier. We also find that the sum of input elasticities $\left(\hat{\beta}_{1}+\hat{\beta}_{2}+\hat{\beta}_{3}\right)$ is 0.90 , indicating that service provision by the Indian Commercial Banks follows a decreasing returns to scale. The Wald Chi-square test for the null hypothesis that the production model exhibits constant returns to scale is rejected at $1 \%$ significance level. The test results also show that the sum of the input elasticities is significantly less than unity, implying that the production function exhibits decreasing returns to scale.

The significantly positive coefficient of the polar-coordinate angle indicates that for a given level of inputs, the frontier output norm depends on the output mix ${ }^{6}$. Due to the inefficiency effects, the observed output norm is obtained by a contraction of the frontier norm. The coefficient estimate of $\theta_{\text {inv }}(\mathrm{rad})$ implies that a decrease in investments on the production frontier results in a more than proportionate increase in loans and advances. This result is in accordance with the idea that making investments in assisted companies, shares, mutual funds, and government securities are more resource consuming than making loans and advances.

The technical efficiency scores are calculated using the estimation results from equations (3.2.5) and (3.2.2) and presented in Table 3. ${ }^{7}$ We find that on average, the efficiency scores of Indian commercial banks are $63.73 \%$ during the period 1989-2009.

\footnotetext{
${ }^{6}$ The output mix represents the different combinations of outputs produced with given resources and technology.

${ }^{7}$ Since we use 1431 observations on banks and calculate technical efficiency of each bank at every time period, we do not report 1431 such scores. Instead we summarize the estimated technical efficiency scores in Table 3. Appendix D presents technical efficiency scores and rank of each bank in our data set.
} 
The estimated efficiency scores suggest that Indian commercial banks were characterized by low technical efficiency during the period under consideration. Further, the public sector banks are found to be technically more efficient compared to private sector banks. Multiple factors account for this high degree of inefficiency. For instance, public sector banks which constitute about $75 \%$ of the financial system, even after reforms, had several social goals including promoting employment in the rural areas, lending to the priority sector ${ }^{8}$ at below-market rates, which ended up in low return on advances and inefficient use of resources from the point of view of output maximization (Das and Ghosh (2006)). Moreover, prevalence of relationship based banking led to significant under-lending by Indian banks (Banerjee et al. (2004)).

The higher technical efficiency scores of public sector banks as opposed to private sector banks, may be the result of public banks catering mostly to government borrowing programs and hence obtaining "significant fee based income from this source". Additionally, public sector banks have always enjoyed the benefits of state support, public confidence with respect to safety of deposits, and provided easy access to subsidized loans to the priority sectors that increase the amount of output, making the banks more efficient compared to other banks (Das and Ghosh (2006); Bhattacharyya et al. (1997)). ${ }^{9}$

Further, the Indian private banks seem to maintain a higher level of efficiency than the foreign private banks in most of the years under consideration. This can be attributed to the fact that the foreign banks that entered the Indian financial market in the early 1990s, needed time to expand their number of branches and acquire stable deposit bases. These foreign banks did not enjoy the advantage of having established business structures and infrastructures as the Indian public and private banks did. Extensive use of costly technology and massive expenditures incurred in trying to push retail loans to expand their asset portfolio also resulted in poor performance of these foreign banks (Sensarma (2006)). However, 2004 onwards, there has not been a significant difference in technical efficiency of Indian and foreign private banks.

\footnotetext{
${ }^{8}$ Priority sectors in India include agriculture, small scale industries, small road and water transport operators, small business, retail trade, professional and self employed persons, organizations for scheduled castes/tribes, education, housing, consumption, software industry etc.

${ }^{9}$ Adjustment of output of public banks by considering the amount of nonperforming loans may reduce the level of efficiency of these banks. However, due to lack of detailed data on losses of public banks due to subsidized loans to favored sectors, an in depth examination of this hypothesis is beyond the scopes of this paper.
} 
A closer look at the time pattern of each bank reveals that technical efficiency of individual banks followed a declining trend for most parts of the period under consideration. ${ }^{10}$ As shown in Table 3 and Figure 1, estimated technical efficiency scores decline over time for public, Indian private, and foreign private banks. However, starting from the middle of 1990's, efficiency of the public banks have changed very little, whereas, efficiency of both Indian private sector and foreign private sector banks have fallen considerably, resulting in an overall lower efficiency of private sector banks as compared to the public banks. An upward trend in the efficiency of private banks is observed only after 2006.

We use the effects of financial reforms and other bank specific characteristics (equation (3.2.6)) to analyze the observed behavior of technical efficiency of Indian commercial banks during the post-reform period. The following subsection presents a discussion of the results.

\subsection{Effects of Reforms on Technical Efficiency}

Table 4 shows the fixed effect estimates of equation (3.2.6). We estimate the model for the entire banking sector and also for different ownership groups. Column (1) shows the estimates for both public sector and private sector banks. Column (2) presents estimates for public sector banks only and column (3) for private commercial banks. We estimate the coefficient of financial reform dummies 1993-1996, 1998-2001, 2002-2005 and 2006-2009 controlling for the number of branches and capital adequacy ratio.

Number of branches is statistically insignificant for All Banks as well as Public and Private sector banks. Capital adequacy ratio (CAR) has significant adverse effects on technical efficiency of sample banks. The coefficient is interpreted as follows: a one percent increase in CAR results in a 0.009 percent decrease in technical efficiency for all banks (Column (1)). The estimate is also significant at the $1 \%$ level. We interpret the coefficient for different ownership groups in the same way. The effect is consistent in sign for different categories of banks. This supports the "conservative behavior" hypothesis discussed in Bhattacharyya et al. (1997). A high CAR implies that banks are significantly risk-averse. Low risk is also associated with low return. A high CAR therefore indicates that banks have a majority low return assets in their portfolio

\footnotetext{
${ }^{10}$ Estimated value of $\eta$ is -0.03 and significant at $5 \%$ level (see Table 2).
} 
which adversely affects their technical efficiency. Strict CAR requirements prescribed in the financial reforms may be partly responsible for this (Shanmugam and Das (2004)).

The reform dummies accounting for post 1992 and post 1997 banking reform periods are statistically significant at the 1\% level for "All Banks". The 1993-1996 dummy is positive and all other reform dummies are negative showing that there was an initial improvement in technical efficiency due to the reforms followed by consistent decline. These effects are also observed for both public and private sector banks. Our findings are consistent with Das et al. (2005) and Zhao et al. (2010).

The results presented in Table 4 clearly indicates that although both phases of reforms were aimed at improving bank efficiency, the outcomes from the two phases were starkly different. A deeper scrutiny of the reforms is thus warranted.

It may be noted that while the 1991-92 reforms aimed at lowering the banks' regulatory costs and enhancing competition, the 1997-98 reforms targeted greater financial stability. In other words, the reforms were a combination of both deregulation and "prudential re-regulation" policies.

The salient features of the 1991-92 reforms include deregulation of interest rates, introduction of risk-asset ratios for banks, simplification of lending structures, removal of capital market restrictions on pricing and issues of capital (Lawrence and Longjam (2003)). These deregulations had a positive impact on efficiency levels of Indian commercial banks, especially the private sector banks.

The second major phase of reforms launched in 1997-98 focussed more on increasing bank stability and hence lower risk-taking. The down-side of such regulatory policies is increase in costs and slow-down in competition (Zhao et al. (2010)). The effect of reforms is also contingent on the performance of the economy in general. For instance, as noted in Banerjee et al. (2004), changes in regulations also affected the criteria of priority sector lending providing smaller firms in the economy with a greater increase in credit limit compared to larger firms. After this change was put into effect in 1998, small firms grew at a rate of $7.6 \%$, while large firms grew at a rate of $11.3 \%$; moreover, $5.96 \%$ of small firms as opposed to $2.5 \%$ of large firms in Mumbai defaulted on their loans - clearly revealing misallocation of loans by banks. The interest rate charged on these loans was also way below the market rate. The misallocation of loans also 
stemmed from the inability of banks to identify "promising firms" when the banks were allowed to have their own independent lending policies in mid-1997. Post 1997 reforms also included stricter vigilance policies. While this was meant to boost bank confidence, it ended up spreading a "fear psychosis", and, banks cut their lending substantially for the fear of being investigated (Banerjee et al. (2004)).

However, the technical efficiency scores, as shown in Table 3, show improvement towards the end of the sample period. We can therefore conclude that although the reforms have had varied impact on technical efficiency in different periods of time and posed challenges to banks in terms of adjusting to a new set of rules and regulations, the banks have adapted to the changed environment and started to show improvements in efficiency. The slow adjustment is not unusual, given the time-lag involved between the implementation and effect of any policy.

While we provide some justification to the observed behavior in technical efficiency of Indian banks in the post-reform period, we also acknowledge that our models may not capture some important characteristics of the banking industry due to data constraints. Future research may aim at including more bank specific features to analyze the effect of reforms on technical efficiency. Since our results are based on an unbalanced panel we re-estimate our models (equations (3.2.5) and (3.2.6)) with a balanced panel data as a robustness check of our findings and report the results below.

\subsection{Robustness Check}

We perform a robustness check of our regression models by using a balanced panel for the period 1995-2007. We estimate technical efficiency of 46 banks in stage 1 regression and analyze the effects of financial reforms on measured technical efficiency scores in the second stage. Tables 5 and 6 in Appendix $C$ report the results of the balanced panel analysis. These results show that our estimates for the unbalanced panel are robust. Number of branches, however, is now statistically significant and negative for all banks in the sample (column (1)) and private sector banks (column (3)). The negative value of the estimate shows that technical efficiency may suffer due to management inefficiencies in the presence of large number of branches, supporting "the bad-management hypothesis" of Berger and DeYoung (1997). 


\section{Conclusion}

In this study we estimate technical efficiency of Indian banks using a multiple-output generalized stochastic production frontier and examine effects of economic reforms on the measured efficiency of banks. None of the existing studies in this field has used a stochastic frontier framework to measure efficiency of banks when banks produce multiple outputs. We fill up this gap in the literature by using bank-level panel data from 1989-2009, estimating technical efficiency of Indian banks.

Although we have restricted the multiple-output model to using only two types of output due to data restrictions, the model can be used to include as many outputs as possible. Extending the model to include more than two outputs may increase the accuracy of the estimates. We also acknowledge that the inherent limitation of the ray production function is its assumption that the disturbance terms affect the output vector multiplicatively, implying that all output dimensions are

proportionally affected by the same disturbance. However, this restrictive assumption is necessary to allow a modeling of multiple-output and multiple-input technologies. To our knowledge there is no better method available at present to address this issue.

Our results show that technical efficiency of Indian banks are low (64\% on average) and declines consistently before increasing towards the end of the sample period. We speculate the reasons for low technical efficiency to be insufficient deposit base for newer banks and too many social purposes of the government, among others. The 1991-92 reforms included mostly deregulatory policies and improved technical efficiency of banks. The post 1997 reforms put more emphasis on bank stability and resulted in loss of efficiency. The time-lag involved in the implementation of government policies and slow adjustment of banks to changing financial environment are possible reasons for the later improvement in efficiency.

Although we try to control for bank specific factors like number of branches and capital adequacy ratio, there may be other important factors such as non-performing assets, rural and urban banking, bank mergers, bureaucratic sloth and others, which we do not consider, mostly due to data unavailability.

The findings of the paper suggest that the financial reforms implemented in India in the early and late 1990s had varied impact on the efficiency of the banking sector. The banking sector, however, continues to show a high degree of inefficiency in the post-reform period. 
Table 1: Summary Statistics

\begin{tabular}{|c|c|c|c|c|c|}
\hline Variable & Mean & $\begin{array}{l}\text { Standard } \\
\text { Deviation }\end{array}$ & Minimum & Maximum & $\begin{array}{c}\text { Number of } \\
\text { Observations }\end{array}$ \\
\hline
\end{tabular}

\begin{tabular}{lccccc} 
Stage 1 & \multicolumn{1}{l}{} \\
\hline Ln(Output norm) & 7.48 & 2.30 & -0.09 & 13.32 & 1431 \\
Ln(Deposits) & 7.62 & 2.59 & -4.61 & 13.52 & 1431 \\
Ln(Labor) & 3.60 & 2.37 & -3.91 & 9.19 & 1431 \\
Ln(Capital) & 2.88 & 1.95 & -3.22 & 8.00 & 1431 \\
$\operatorname{Ln}\left(\theta_{\text {inv }}\right)$ & -0.20 & 0.62 & -6.47 & 0.42 & 1431 \\
\hline
\end{tabular}

Stage 2

\begin{tabular}{lccccc}
\hline Ln(Technical Efficiency) & -0.40 & 0.23 & -1.82 & -0.02 & 603 \\
Ln(No. of Branch) & 6.08 & 1.49 & 0.00 & 9.35 & 603 \\
Ln(Capital Adequacy Ratio) & 2.46 & 0.37 & -2.81 & 4.10 & 603 \\
\hline
\end{tabular}

Notes: Stage 1 variables are measured in millions of Indian rupees 
Table 2: Measuring Technical Efficiency with Unbalanced Panel

\begin{tabular}{lc}
\hline & Dependent Variable: Ln(Output) \\
\hline Variables & Ln(Output) \\
\hline Ln(Deposit) & $0.191^{* * *}$ \\
& $(0.012)$ \\
Ln(Labor) & $0.299^{* * *}$ \\
& $(0.021)$ \\
Ln(Capital) & $0.409^{* * *}$ \\
& $(0.026)$ \\
Ln $\left(\theta_{\text {inv }}(\right.$ rad $\left.)\right)$ & $0.034^{*}$ \\
Yearid & $(0.020)$ \\
& $0.044^{* * *}$ \\
Constant & $(0.004)$ \\
& $3.686^{* * *}$ \\
$\eta$ & $(0.089)$ \\
Observations & $-0.030^{* * *}$ \\
Number of Companyid & $(0.006)$ \\
Wald $\chi^{2}(5)$ & 1431.00 \\
\hline \hline
\end{tabular}

Notes: ${ }^{* * *} \mathrm{p}<0.01,{ }^{*} \mathrm{p}<0.1$. Standard errors in parentheses.

Coefficient estimates of $\ln ($ Deposit), $\ln ($ Labor), and $\ln$ (Capital) represent elasticity of output with respect to deposit, labor and capital respectively.

Estimated coefficient of Yearid represents change in the actual output due to technological changes over time.

Sign of estimated $\eta$ implies the direction of change in technical efficiency over time. 


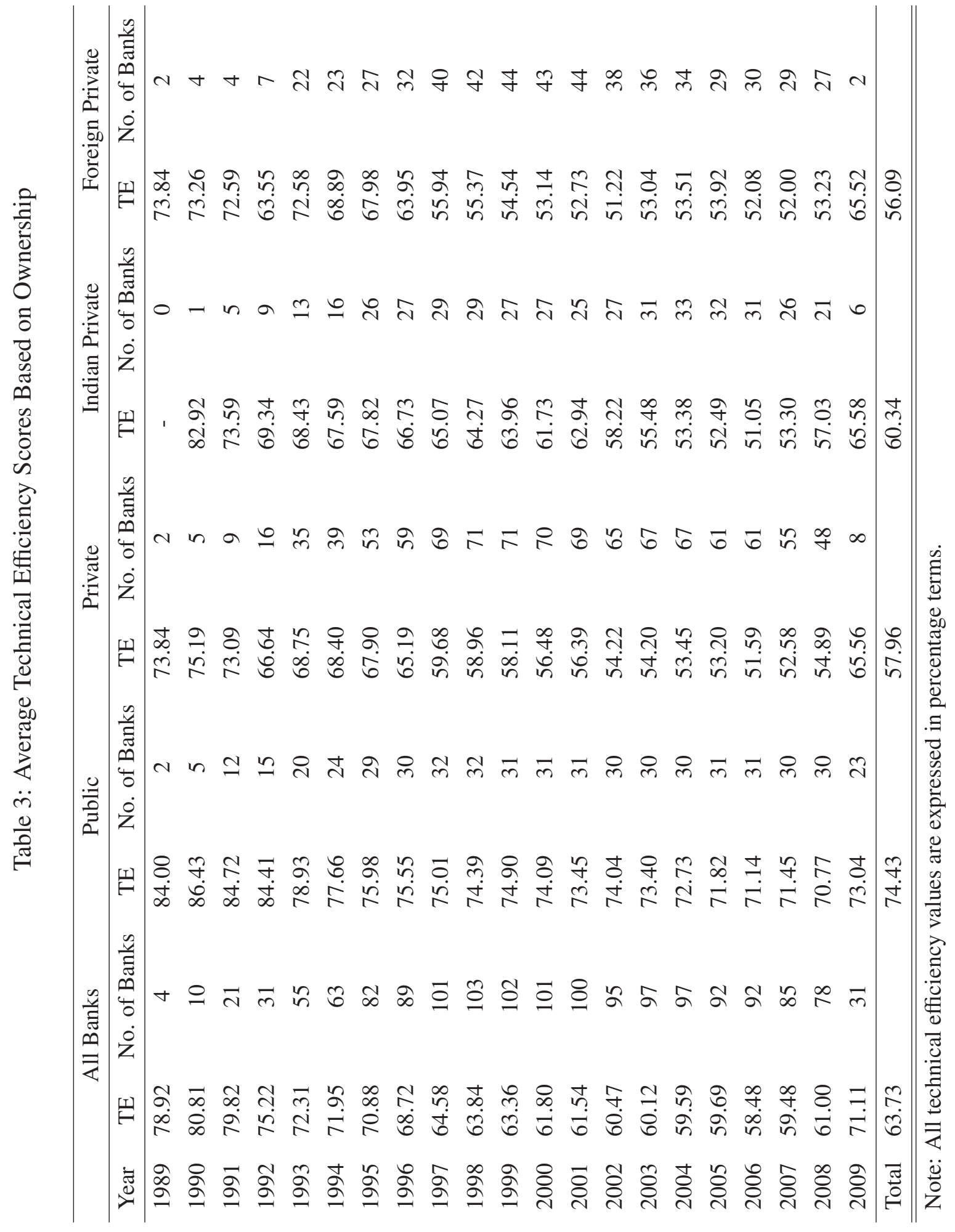


Table 4: Effects of Financial Reforms on Technical Efficiency - Unbalanced Panel Dependent Variable: Ln(Technical Efficiency)

\begin{tabular}{|c|c|c|c|}
\hline & (1) & (2) & (3) \\
\hline Variables & All Banks & Public & Private \\
\hline \multirow[t]{2}{*}{ Ln( No. of Branch) } & 0.002 & -0.013 & 0.009 \\
\hline & $(0.005)$ & $(0.024)$ & $(0.006)$ \\
\hline \multirow[t]{2}{*}{ Ln(Capital Adequacy Ratio) } & $-0.009 *$ & -0.008 & $-0.011 *$ \\
\hline & $(0.005)$ & $(0.006)$ & $(0.007)$ \\
\hline \multirow[t]{2}{*}{ 1993-1996 } & $0.028 * * *$ & 0.009 & $0.038 * * *$ \\
\hline & $(0.008)$ & $(0.006)$ & $(0.011)$ \\
\hline \multirow[t]{2}{*}{ 1998-2001 } & $-0.019 * * *$ & $-0.017 * * *$ & $-0.027 * * *$ \\
\hline & $(0.004)$ & $(0.003)$ & $(0.007)$ \\
\hline \multirow[t]{2}{*}{ 2002-2005 } & $-0.062 * * *$ & $-0.054 * * *$ & $-0.077 * * *$ \\
\hline & $(0.006)$ & $(0.006)$ & $(0.010)$ \\
\hline \multirow[t]{2}{*}{ 2006-2009 } & $-0.103 * * *$ & $-0.087 * * *$ & $-0.131 * * *$ \\
\hline & $(0.008)$ & $(0.009)$ & $(0.015)$ \\
\hline \multirow[t]{2}{*}{ Constant } & $-0.333 * * *$ & -0.154 & $-0.442 * * *$ \\
\hline & $(0.034)$ & $(0.171)$ & $(0.030)$ \\
\hline Observations & 603 & 319 & 284 \\
\hline Adj. R-squared & 0.718 & 0.749 & 0.74 \\
\hline Number of companyid & 72 & 30 & 42 \\
\hline
\end{tabular}

$* * * \mathrm{p}<0.01, * \mathrm{p}<0.10$.

Robust standard errors clustered at bank level in parentheses.

A one percent increase in CAR results in a $0.009 \%$ decrease in technical efficiency

for All banks in the sample.

Estimates of the year-dummies show effects of different phases of reforms.

Reform coefficient estimates are negative and significant at the $1 \%$ level

for All banks in the sample 
Figure 1: Average Technical Efficiency Scores of Sample Banks

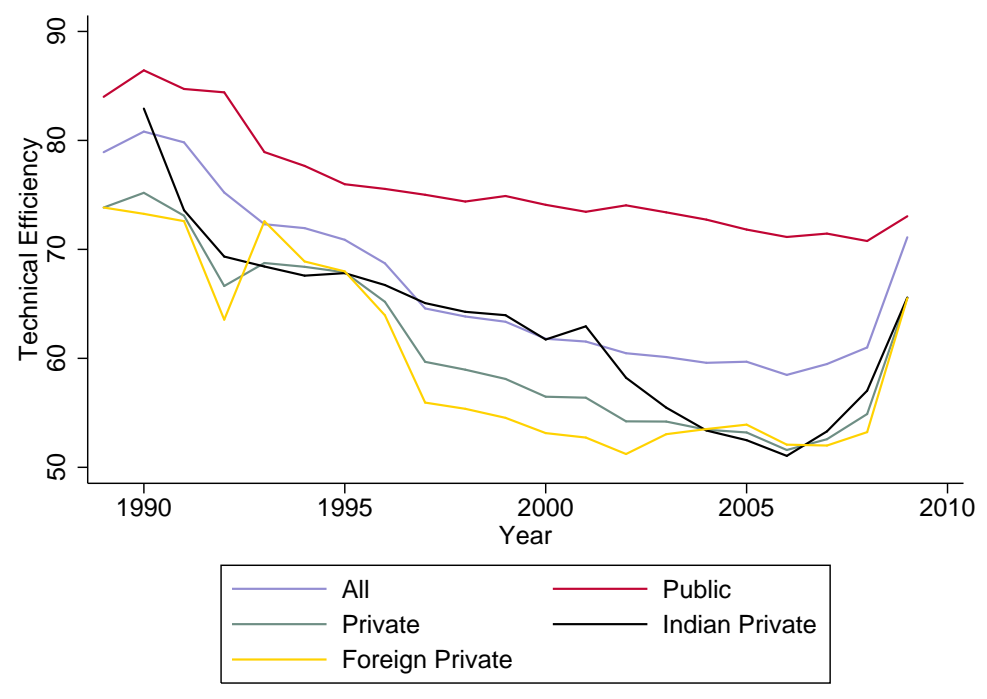




\section{Appendices}

\section{A Description of Variables}

Investment- Investment in assisted companies, shares, mutual funds, government securities, etc.

Loans - Loans and advances made by banks.

Deposits - Deposits accepted by commercial banks. There are three types of deposits: demand deposits, savings deposits and term deposits. This data field captures the total deposits collected and outstanding with the bank.

Labor - Measured by compensation to employees. It includes payments made in cash or kind by companies to their employees. Such expenses include salaries, bonus, contribution to provident funds, training costs, and other labor related expenses.

Capital - Sum of expenses on power, fuel and water, payment of indirect taxes e.g. service tax, rents and lease rents, repair expenses, printing and stationary expenses and depreciation.

Output - Eucledian norm of two types of output vectors - investment, and loans and advances.

Capital Adequacy ratio - Banks are required to maintain a certain amount of capital in relation to other assets, such as, loans and investments as a cover against possible losses in these assets. Capital adequacy ratio is the percentage of the total capital funds to the total risk-weighted assets. 


\section{B Generalized Stochastic Production Frontier}

A multiple-output generalized stochastic production model (Löthgren(1997)) defines a ray production function based on polar coordinates, allowing for the primal-based estimation of multiple output production frontiers and bank specific technical efficiencies that vary over time. The output mix is represented by the output polar-coordinate angles. For a given output mix and input level, the generalized production function, also known as the ray production function, gives the maximum Euclidean norm of the output vector that is attainable given the technology. Formally, for a production technology with multiple inputs, $x \in R_{+}^{d}$, that are used to produce multiple outputs $y \in R_{+}^{p}$, the generalized production function represents the output vector in polar-coordinate form as

$$
y=l \cdot m(\theta)
$$

where $l=l(y)=\|y\|=\left(\sum_{i=1}^{p} y_{i}^{2}\right)^{1 / 2}$ denotes the Euclidean norm of the outputs, $m(\theta)=y /\|y\|$ represents the transformation function of the polar-coordinate angles $\theta$ to the output mix vector.

The function $m:[0, \pi / 2]^{p-1} \rightarrow[0,1]^{p}$ is defined in terms of the output polar-coordinate angles as

$$
m_{i}(\theta)=\cos \theta_{i} \prod_{j=0}^{i-1} \sin \theta_{j}, i=1, \ldots, p
$$

where $\theta \in[0, \pi / 2]^{p-1}$, and $\sin \theta_{0}=\cos \theta_{p}=1$.

The polar coordinate angles $\theta$ are obtained recursively from the inverse transformation $m^{-1}(y /\|y\|)$ as

$$
\theta_{i}(y)=\cos \left(y_{i} /\|y\| \prod_{j=0}^{i-1} \sin \theta_{j}\right), i=1, \ldots, p
$$

The first angle is given by $\theta_{1}=\cos ^{-1}\left(y_{1} /\|y\|\right)$, which is used in the calculation of the second angle $\theta_{2}=\cos ^{-1}\left(y_{2} /\|y\| \sin \theta_{1}\right)$

The remaining angles $\theta_{i}, i=3, \ldots, p-1$ are calculated following continuous recursion.

The ray production function, as illustrated by Löthgren(1997), is closely related to the output distance function in (Shephard (1970)). This output distance function is defined as

$$
D_{0}(x, y)=\min \{\delta>0: y / \delta \in P(x)\}
$$


where, $P(x)=\left\{y \in R_{+}^{p}: x\right.$ can produce $\left.y\right\}$ is the output set. Given weak disposability of outputs ${ }^{11}$, the output distance function provides a complete representation of the technology (Färe (1988)) in the sense that

$$
D_{0}(x, y) \leq 1 \Leftrightarrow y \in P(x)
$$

The isoquant of the output set, or the output frontier is defined as

$$
\operatorname{Isoq} P(x)=\{y: y \in P(x), \lambda y \notin P(x), \lambda y>1\}
$$

If $D_{0}(x, y)=1$, then the output is technically efficient and belongs to the output frontier. On the other hand, $D_{0}(x, y)<1$ signifies technical inefficiency or output being lower than the frontier level.

The ray production function provides a generalization of the single-output production function to multiple-output technologies as output distance function. Formally, the ray production function is given by

$$
f(x, \theta)=\max \{l \geq 0: l \cdot m(\theta) \in P(x)\}
$$

The output distance function is given by the ratio of the output norm to the frontier output norm (Färe (1988)). Since, by definition $y=l \cdot m(\theta)$ and $f(x, \theta) \cdot m(\theta)$ belongs to the isoquant (frontier) of the output set, the distance function can be expressed in terms of the ray production function as

$$
D_{0}(x, y)=\|y\| /\left\|y^{f}\right\|=\|y\| / f(x, \theta)
$$

The curvature of the production frontier can be derived from the partial derivatives of the ray function with respect to the polar-coordinate angles, $\partial f(x, \theta) / \partial \theta_{i}, i=1, \ldots, p-1$.

For a given level of inputs, $\partial f(x, \theta) / \partial \theta_{i}$ captures the change in the output norm when the output mix changes along the frontier (Gerdtham et al. (1999)). For example, for a technology with three outputs, the first angle $\theta_{1}$ represents the angle from $y_{1}$ axis towards the plane spanned by the $y_{2}$ and $y_{3}$ axis. $\theta_{2}$ represents the angle between $y_{2}$ and $y_{3}$ in the $y_{2}-y_{3}$ plane. Therefore, the derivative $\partial f(x, \theta) / \partial\left(\theta_{1}\right)$ represents the change of the frontier output norm for changes in

\footnotetext{
${ }^{11}$ Weak disposability of outputs implies that proportional reduction in inputs is feasible.
} 
the output mix along the output frontier with fixed proportions between $y_{2}$ and $y_{3}$. Similarly, $\partial f(x, \theta) / \partial\left(\theta_{2}\right)$ represents the change of the frontier output norm for changes in the output mix with the level of $y_{1}$ held constant. A ray production function for a two-output technology is illustrated in Figure 2.

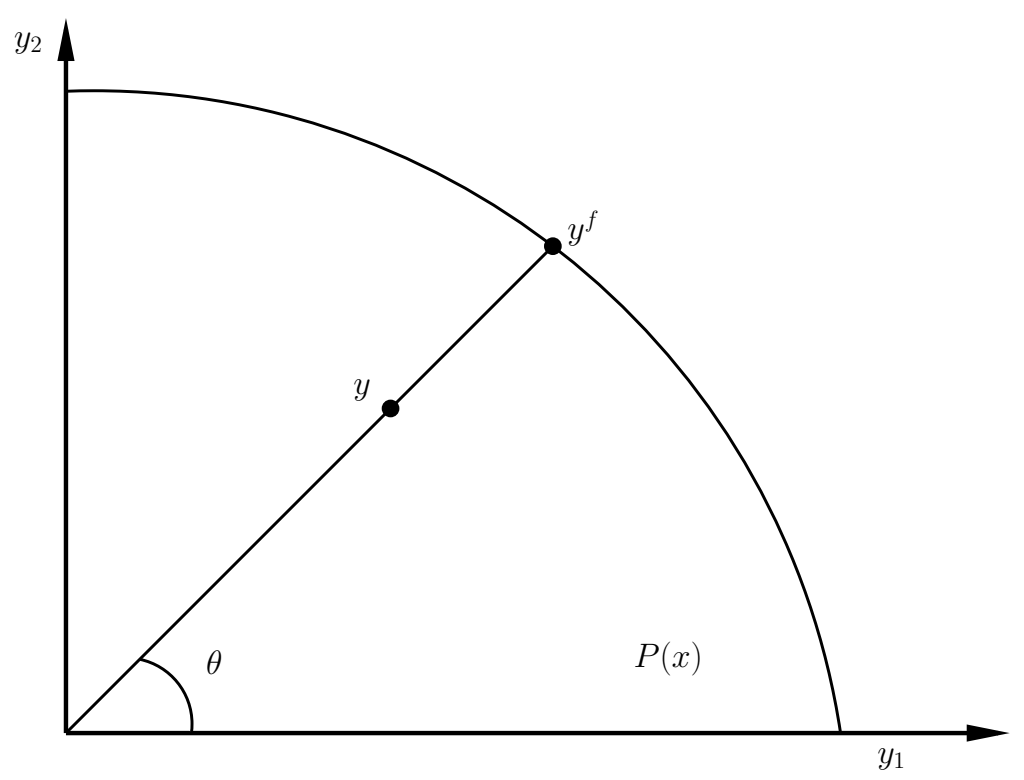

Figure 2: $\mathrm{P}(\mathrm{x})$ is the output set. The output mix of the output $\mathrm{y}$ is represented by the angle $\theta \cdot y^{f}=f(x, \theta) \cdot m(\theta)$ is the ray production function or the frontier output. Output y is technically inefficient. 


\section{Balanced Panel Regression Results}

Table 5: Measuring Technical Efficiency with Balanced Panel (1995-2007)

\begin{tabular}{lc} 
& Dependent Variable: Ln(Output) \\
\hline Variables & Ln(Output) \\
\hline Ln(Deposit) & $0.659 * * *$ \\
& $(0.022)$ \\
Ln(Labor) & $0.065^{* * *}$ \\
& $(0.018)$ \\
Ln(Capital) & $0.156^{* * *}$ \\
& $(0.025)$ \\
Ln( $\theta_{\text {inv }}($ rad $\left.)\right)$ & $-0.050^{* * *}$ \\
& $(0.015)$ \\
Yearid & $0.081 * * *$ \\
& $(0.007)$ \\
Constant & $2.106 * * *$ \\
Wald $\chi^{2}(5)$ & $(0.161)$ \\
\hline & $-0.051 * * *$ \\
Observations & $(0.007)$ \\
Number of companyid & 46.00 \\
& 4303.76 \\
\hline
\end{tabular}

Notes: $* * * \mathrm{p}<0.01, * \mathrm{p}<0.10$. Standard errors in parentheses.

Coefficient estimates of $\ln$ (Deposit), $\ln ($ Labor $)$, and $\ln$ (Capital) represent

elasticity of output with respect to deposit, labor and capital respectively.

Signs of estimated $\eta$ implies the direction of change in technical

efficiency over time. 
Table 6: Effect of Reforms on Technical Efficiency - Balanced Panel (1995-2007)

Dependent Variable: Ln(Technical Efficiency)

\begin{tabular}{lccc}
\hline & $(1)$ & $(2)$ & $(3)$ \\
Variables & All Banks & Public & Private \\
& & & \\
\hline Ln(No. of Branch) & $-0.093^{*}$ & -0.054 & $-0.114^{* *}$ \\
& $(0.049)$ & $(0.046)$ & $(0.048)$ \\
Ln(Capital Adequacy Ratio) & $-0.014^{* * *}$ & -0.019 & $-0.014^{* * *}$ \\
& $(0.006)$ & $(0.011)$ & $(0.004)$ \\
1998-2000 & $-0.075^{* * * *}$ & $-0.067^{* * *}$ & $-0.107 * * *$ \\
& $(0.009)$ & $(0.005)$ & $(0.021)$ \\
2001-2003 & $-0.197 * * *$ & $-0.184^{* * *}$ & $-0.240^{* * *}$ \\
& $(0.011)$ & $(0.008)$ & $(0.024)$ \\
2004-2007 & $-0.356^{* * * *}$ & $-0.333^{* * *}$ & $-0.420^{* * *}$ \\
& $(0.016)$ & $(0.014)$ & $(0.030)$ \\
Constant & -0.016 & -0.179 & -0.104 \\
& $(0.325)$ & $(0.337)$ & $(0.252)$ \\
Observations & 313 & 212 & 101 \\
Adj. R-squared & 0.889 & 0.897 & 0.898 \\
Number of companyid & 35 & 22 & 13 \\
\hline
\end{tabular}

*** $\mathrm{p}<0.01, * * \mathrm{p}<0.05, * \mathrm{p}<0.10$.

Robust standard errors clustered at bank level in parentheses. 


\section{Table: Average Bank Technical Efficiency Scores}

Average Technical Efficiency Scores of Banks - Highest to Lowest

\begin{tabular}{|c|c|c|}
\hline Bank & TE & Rank \\
\hline I D B I Bank Ltd & 97.82 & 1 \\
\hline Bank of Nova Scotia & 94.04 & 2 \\
\hline British Bank of the Middle East & 93.91 & 3 \\
\hline Antwerp Diamond Bank N V & 93.91 & 4 \\
\hline State Bank of India & 93.11 & 5 \\
\hline Jammu \& Kashmir Bank Ltd. & 92.07 & 6 \\
\hline I C I C I Bank Ltd. & 92.06 & 7 \\
\hline Indusind Bank Ltd. & 91.38 & 8 \\
\hline Bank of India & 89.19 & 9 \\
\hline Global Trust Bank & 84.94 & 10 \\
\hline Oriental Bank of Commerce & 84.34 & 11 \\
\hline Sakura Bank Ltd. & 84.13 & 12 \\
\hline Credit Lyonnais & 82.98 & 13 \\
\hline UCO Bank & 82.66 & 14 \\
\hline Union Bank of India & 81.87 & 15 \\
\hline State Bank of Patiala & 81.8 & 16 \\
\hline Bank of Baroda & 81.69 & 17 \\
\hline Indian Overseas Bank & 80.71 & 18 \\
\hline Canara Bank & 80.62 & 19 \\
\hline Axis Bank Ltd. & 80.44 & 20 \\
\hline Central Bank of India & 80.28 & 21 \\
\hline State Bank of Hyderabad & 79.88 & 22 \\
\hline Punjab National Bank & 79.68 & 23 \\
\hline Bank of America & 79.64 & 24 \\
\hline Corporation Bank & 79.53 & 25 \\
\hline
\end{tabular}


Table continued from previous page

\begin{tabular}{|l|c|c|}
\hline \multicolumn{1}{|c|}{ Bank } & TE & Rank \\
\hline United Bank of India & 78.36 & 26 \\
Federal Bank Ltd. & 78.08 & 27 \\
Karnataka Bank Ltd. & 77.48 & 28 \\
State Bank of Travancore & 76.53 & 29 \\
Abu Dhabi Commercial Bank & 76.01 & 30 \\
Allahabad Bank & 74.91 & 31 \\
Syndicate Bank & 74.78 & 32 \\
Indian Bank & 74.51 & 33 \\
American Express Intl. Banking Corpn. & 73.61 & 34 \\
State Bank of Indore & 72.07 & 35 \\
J P Morgan Chase Bank & 70.81 & 36 \\
H D F C Bank Ltd. & 69.84 & 37 \\
Vijaya Bank & 69.36 & 38 \\
Pinakini Grameena Bank & 68.98 & 39 \\
Bank of Maharash & 68.77 & 40 \\
I D B I Bank Ltd. & 68.75 & 41 \\
Toronto-Dominion Bank & 68.34 & 42 \\
I N G Vysya Bank & 68.29 & 43 \\
Andhra Bank & 68.13 & 44 \\
State Bank of Mysore & 67.63 & 45 \\
State Bank of Bikaner \& Jaipur & 67.55 & 46 \\
Karur Vysya Bank & 67.03 & 47 \\
Yes Bank Ltd. & 66.83 & 48 \\
A B N-Amro Bank N V & 66.8 & 49 \\
U F J Bank Ltd. & 66.22 & 50 \\
Punjab \& Sind Bank & 66.09 & 51 \\
South Indian Bank & & 52 \\
\hline & & \\
\hline
\end{tabular}


Table continued from previous page

\begin{tabular}{|l|c|c|}
\hline \multicolumn{1}{|c|}{ Bank } & TE & Rank \\
\hline Citibank N A. & 65.74 & 53 \\
Standard Chartered Bank & 65.39 & 54 \\
City Union Bank & 65.33 & 55 \\
United Western Bank & 64.92 & 56 \\
Societe Generale & 64.64 & 57 \\
Sumitomo Bank Ltd. & 64.42 & 58 \\
Dena Bank & 63.86 & 59 \\
Calyon Bank & 63.79 & 60 \\
State Bank of Saurashtra & 63.28 & 61 \\
Banque Nationale de Paris & 62.84 & 62 \\
Tamilnad Mercantile Bank Ltd. & 62.18 & 63 \\
State Bank of Mauritius Ltd. & 60.86 & 64 \\
Hongkong \& Shanghai Bank & 60.72 & 65 \\
Lakshmi Vilas Bank Ltd. & 58.61 & 66 \\
Times Bank Ltd. & 57.82 & 67 \\
Bank of Punjab Ltd. & 57.67 & 68 \\
Development Credit Bank Ltd. & 56.48 & 69 \\
Bank of Rajasthan Ltd. & 55.26 & 70 \\
Deutsche Bank A G & 55.11 & 71 \\
D B S Bank Ltd. & 54.48 & 72 \\
Standard Chartered Grindlays Bank Ltd. & 54.39 & 73 \\
S B I Commercial \& International Bank Ltd. & 54.15 & 74 \\
Bank of Tokyo-Mitsubishi U F J Ltd. & 53.1 & 75 \\
Benares State Bank Ltd. & 52.82 & 76 \\
Siam Commercial Bank & 51.88 & 77 \\
Mizuho Corporate Bank Ltd. & 51.4 & 78 \\
Bank of Madura Ltd. & 51.34 & 79 \\
\hline & & \\
\hline
\end{tabular}


Table continued from previous page

\begin{tabular}{|l|c|c|}
\hline \multicolumn{1}{|c|}{ Bank } & TE & Rank \\
\hline Nedungadi Bank Ltd. & 51.06 & 80 \\
Dhanalakshmi Bank Ltd. & 50.55 & 81 \\
Sangli Bank Ltd. & 50.21 & 82 \\
Catholic Syrian Bank Ltd. & 50 & 83 \\
Centurion Bank of Punjab Ltd. & 49.67 & 84 \\
Barclays Bank Plc. & 49.52 & 85 \\
B N P Paribas & 49.51 & 86 \\
Kotak Mahindra Bank Ltd. & 49.24 & 87 \\
Bank of Ceylon & 48.38 & 88 \\
Bharat Overseas Bank Ltd. & 47.78 & 89 \\
Ganesh Bank of Kurundwad Ltd. & 46.15 & 90 \\
Bank of Bahrain & 45.75 & 91 \\
Chase Manhattan Bank N A & 45.57 & 92 \\
Mashreqbank P S C & 45.47 & 93 \\
Nainital Bank Ltd. & 44.27 & 94 \\
Vinayak Local Area Bank Ltd. & 43.33 & 95 \\
Lord Krishna Bank Ltd. & 43.22 & 96 \\
Bareilly Corporation Bank Ltd. & 42.16 & 97 \\
Oman International Bank & 41.75 & 98 \\
Sumitomo Mitsui Banking Corpn. & 38.6 & 99 \\
American Express Bank Ltd. & 38.43 & 100 \\
Ratnakar Bank Ltd. & 36.39 & 101 \\
Santhal Parganas Gramin Bank & 36.22 & 102 \\
I N G Bank N V & 35.93 & 103 \\
Karad Urban Co-op Bank Ltd. & 35.73 & 104 \\
Mapusa Urban Co-op Bank Ltd. & 35.69 & 105 \\
Shinhan Bank & 35.22 & 106 \\
\hline & & \\
\hline
\end{tabular}


Table continued from previous page

\begin{tabular}{|l|c|c|}
\hline \multicolumn{1}{|c|}{ Bank } & TE & Rank \\
\hline Cho Hung Bank & 33.81 & 107 \\
Commerzbank A G & 32.92 & 108 \\
Bank Muscat S A & 32.83 & 109 \\
Chinatrust Commercial Bank & 32.37 & 110 \\
Mahakaushal Kshetriya Gramin Bank & 32.17 & 111 \\
Capital Local Area Bank Ltd. & 30.94 & 112 \\
K B C Bank N V. & 30.35 & 113 \\
Shri Arihant Co-op Bank Ltd. & 29.21 & 114 \\
Dresdner Bank A. G. & 26.14 & 115 \\
Sree Narayana Guru Co-op Bank Ltd. & 22.39 & 116 \\
Bank International Indonesia & 21.52 & 117 \\
Krishna Bhima Bank Ltd. & 18.11 & 118 \\
A B Bank Ltd. & 17.05 & 119 \\
Oversea-Chinese Banking Corpn. Ltd. & 16.77 & 120 \\
Shreeji Bhatia Co-op Bank Ltd. & 16.47 & 121 \\
Bank Muscat Al Ahli & 14.9 & 122 \\
Krung Thai Bank & 11.81 & 123 \\
South Gujarat Local Area Bank Ltd. & 10.69 & 124 \\
Sonali Bank & 8.04 & 125 \\
\hline \hline
\end{tabular}




\section{References}

Abiad, Abdul, Nienke Oomes, and Kenichi Ueda, "The quality effect: Does financial liberalization improve the allocation of capital?," Journal of Development Economics, 2008, 87 (2), 270-282.

Ahluwalia, Montek S., "Economic reforms in India since 1991: has gradualism worked?," The Journal of Economic Perspectives, 2002, 16 (3), 67-88.

Banerjee, A., S. Cole, and E. Duflo, "Banking reform in India," in "India Policy Forum," Vol. 1 2004, pp. 277-323.

Barth, J.R., G. Caprio, and R. Levine, Rethinking bank regulation: till angels govern, Cambridge Univ Pr, 2006.

Berger, Allen N. and Robert DeYoung, "Problem loans and cost efficiency in commercial banks," Journal of Banking $\mathcal{F}$ Finance, 1997, 21 (6), 849-870.

Bhattacharyya, Arunava, C.A.K. Lovell, and Pankaj Sahay, "The impact of liberalization on the productive efficiency of Indian commercial banks," European Journal of Operational Research, 1997, 98 (2), 332-345.

Das, Abhimaan and Saibal Ghosh, "Financial deregulation and efficiency: An empirical analysis of Indian banks during the post reform period," Review of Financial Economics, 2006, 15 (3), 193-221.

_, Ashok Nag, and Subhash C. Ray, "Liberalisation, Ownership and Efficiency in Indian Banking: A Nonparametric Analysis," Economic and Political Weekly, 2005, pp. 1190-1197.

Das, Abhiman and Subal C. Kumbhakar, "Productivity and efficiency dynamics in indian banking: an input distance function approach incorporating quality of inputs and outputs," Journal of Applied Econometrics, 2010.

Färe, R., Fundamentals of production theory, Springer-Verlag, 1988. 
Fry, Maxwell J., “Money and capital or financial deepening in economic development?,' Journal of Money, Credit and Banking, 1978, 10 (4), 464-475.

_ , "Saving, investment, growth and the cost of financial repression," World Development, 1980, $8(4), 317-327$.

Fry, M.J., "In favour of financial liberalisation,” The Economic Journal, 1997, pp. 754-770.

Gerdtham, U.G., M. Löthgren, M. Tambour, and C. Rehnberg, "Internal markets and health care efficiency: a multiple-output stochastic frontier analysis," Health Economics, 1999, 8 (2), $151-164$.

Goldsmith, Raymond W., Financial structure and development, Yale University Press New Haven, 1969.

Haber, S., "Banks, Financial Markets, and Industrial Development," Latin American macroeconomic reforms: the second stage, 2003, p. 257.

King, Robert G. and Ross Levine, "Finance and growth: Schumpeter might be right," The Quarterly Journal of Economics, 1993a, 108 (3), 717-737.

_ and _ , "Finance, entrepreneurship and growth," Journal of Monetary economics, 1993b, 32 (3), 513-542.

Kumar, Sunil and Rachita Gulati, "Did efficiency of Indian public sector banks converge with banking reforms?," International Review of Economics, 2009, 56 (1), 47-84.

Lawrence, P. and I. Longjam, "Financial Liberalisation in India: measuring relative progress," Keele Economics Research Papers, 2003, 8.

Levine, R., "Finance and growth: Theory and evidence," Handbook of economic growth, 2005, $1,865-934$.

Löthgren, Mickael, “Generalized stochastic frontier production models," Economics Letters, 1997, 57 (3), 255-259. 
Mckinnon, Ronald I., Money and Capital in Economic Development, Washington D.C. Brookings Institution, 1973.

Mohan, Rakesh, Financial sector reforms in India: policies and performance analysis, Atlantic Publishers \& Distributors, 2005.

Sathye, Milind, "Efficiency of banks in a developing economy: the case of India," European Journal of Operational Research, 2003, 148 (3), 662-671.

Schumpeter, Joseph A., The Theory of Economic Development, Cambridge Mass: Harvard University Press, 1911.

Sensarma, Rudra, "Are foreign banks always the best? Comparison of state-owned, private and foreign banks in India," Economic Modelling, 2006, 23 (4), 717-735.

Shanmugam, K.R. and A. Das, "Efficiency of Indian commercial banks during the reform period," Applied Financial Economics, 2004, 14 (9), 681-686.

Shaw, E., Financial deepening in Economic growth, New York: Oxford University Press, 1973.

Thomas, Susan, "How the financial sector in India was reformed," Documenting Reforms: Case Studies from India. Observer Research Foundation, 2005.

Zhao, Tianshu, Barbara Casu, and Alessandra Ferrari, "The impact of regulatory reforms on cost structure, ownership and competition in Indian banking," Journal of Banking E Finance, 2010, 34 (1), 246-254. 